\title{
Sir Samuel Wilks (1824-1911): On Epilepsy
}

\author{
J.M.S. Pearce \\ Emeritus Consultant Neurologist, Department of Neurology, Hull Royal Infirmary, Hull, UK
}

\section{Key Words}

Samuel Wilks • Epilepsy • Cortical epileptogenesis • Bromides

\begin{abstract}
Samuel Wilks was one of that remarkable era of great physicians and syndrome creators based at Guy's Hospital in the mid 19th century. He made signal contributions to the concept that epilepsy derived from surface lesions affecting the cortex, as opposed to the medulla. After Locock, he was largely responsible for the general use of bromide - in his day the only effective anticonvulsant.
\end{abstract}

Copyright $\odot 2008$ S. Karger AG, Basel

Sir Samuel Wilks, who succeeded Sir William Gull, was one of the great Guy's Hospital physicians of his era, spanning 1856-1885. Bright, Addison and Hodgkin were his immediate predecessors. Wilks's many original papers on neurological and general medical diseases are considered elsewhere [1]. This paper considers Wilks's contributions to the understanding of epilepsy in the mid 19 th century.

He began to study epilepsy at a time when it was almost defined by the presence of generalized convulsions, and was generally believed to arise in the medulla oblongata. The different patterns of partial seizures were not clearly demarcated, nor did physicians appreciate that the onset and spread of fits betrayed their origin and mode of spread in the cerebrum. Wilks's views have to be brief- ly set against a background of opinions held by contemporaries and predecessors.

Hughlings Jackson [2] described his theory of evolutionary neurophysiology:

'I have long thought that we shall be very much helped in our investigations of diseases of the nervous system by considering them as reversals of evolution, that is, dissolution,'

influenced by Spencer and by the brilliant Estonian embryologist Karl Ernst von Baer (1792-1876). The psychologist and philosopher Herbert Spencer (1820-1903) postulated a hierarchical organization in organs, animals and even societies, with simple systems evolving into complex, interconnected structures. Jackson applied these principles to neurology, especially to the origin and mode of spread of epileptic discharges. He applied the terms evolution and dissolution to the physiological effects of pathological disorders in the brain [3]. This was both a major and a new concept in England, based largely on his own astute clinical observations and inferences. In his 1870 A Study of Convulsions, he proposed that the (Jacksonian) march of focal epilepsy suggested a somatic representation on the cortex through projections to and from the corpus striatum [4]. He was to some extent influenced by Brown-Séquard [5], who published extensively on epilepsy, and who acknowledged Bright, as well as Copland who in 1844 reported 'loss of sensation in one limb and loss of movement in another, on the opposite side' (Dictionary of Practical Medicine, 1844, vol. 1, p. 795). Brown-Séquard [5] located the origins of epilepsy in the medulla or spinal cord ['an irritation starting in some

\section{KARGER}

Fax +4161306 1234

E-Mail karger@karger.ch

www.karger.com
(C) 2008 S. Karger AG, Basel

0014-3022/09/0612-0124\$26.00/0

Accessible online at:

www.karger.com/ene
J.M.S. Pearce

304 Beverley Road

Anlaby, East Yorks HU10 7BG (UK) 
centripetal nerve, and generating convulsions' (p. 180)], in which idea he followed van der Kolk (1797-1862), Kussmaul (1822-1902), and W.A. Hammond (1828-1900) [6]. However, he differed from Brown-Séquard who conceded that it might begin centrally, commenting:

'Physicians admit now, two kinds of epilepsy, one of centric and the other of peripheric origin. I will try to show that although it seems to be of peripheric origin, it may, in some cases, be in reality of centric origin' [7].

The major step forward in epilepsy began with Hughlings Jackson's early papers [8-10]. Jackson gave priority to Theodor Herpin [11] and amply praised his publications [12]:

'I wish to show', says Jackson, 'by the quotations from Herpin [13] that statements essentially the same as those I make were made by a great authority long ago.'

Herpin [12] had emphasized that all epileptic seizures, whether complete or incomplete, began in the same way, and, therefore, must originate in the same locus in the brain.

\section{Wilks and Epilepsy}

In 1868 , the same year as Jackson's paper on epilepsy, Samuel Wilks followed Bright (1831) [14] and Robert Bentley Todd (1849) [15] among the first to implicate the cortex in the genesis of epilepsy. Jackson frequently visited Guy's Hospital and talked to Wilks. It is likely that Wilks's notions influenced Jackson, though uncharacteristically Jackson gives sparse reference to his work. Wilks separated epilepsy as a disease from epileptiform attacks which were the outward manifestations of a cortical, grey matter lesion. He [16] stated:

'We cannot but conclude that the fons et origio mali is in the cineritious ${ }^{1}$ substance of the brain. I believe that in this region a commotion occurs which would perhaps, be analogous to a palpitation affecting the heart, and that this irritates the ganglia below, which form the summit of the motor tracts.'

In Wilks's celebrated book [17] (fig. 1), he recorded:

'Epilepsy. - ... it is necessary first to define the term, and discover what morbid conditions cannot be looked upon as the cause of this disease. Thus, symptoms resembling epilepsy may arise from various causes, as suppression of urine, or from positive disease in the brain, as from tumours, and thus formerly spiculæ of

1 Cineritious, literally ashen, was applied to mean cortical grey matter.

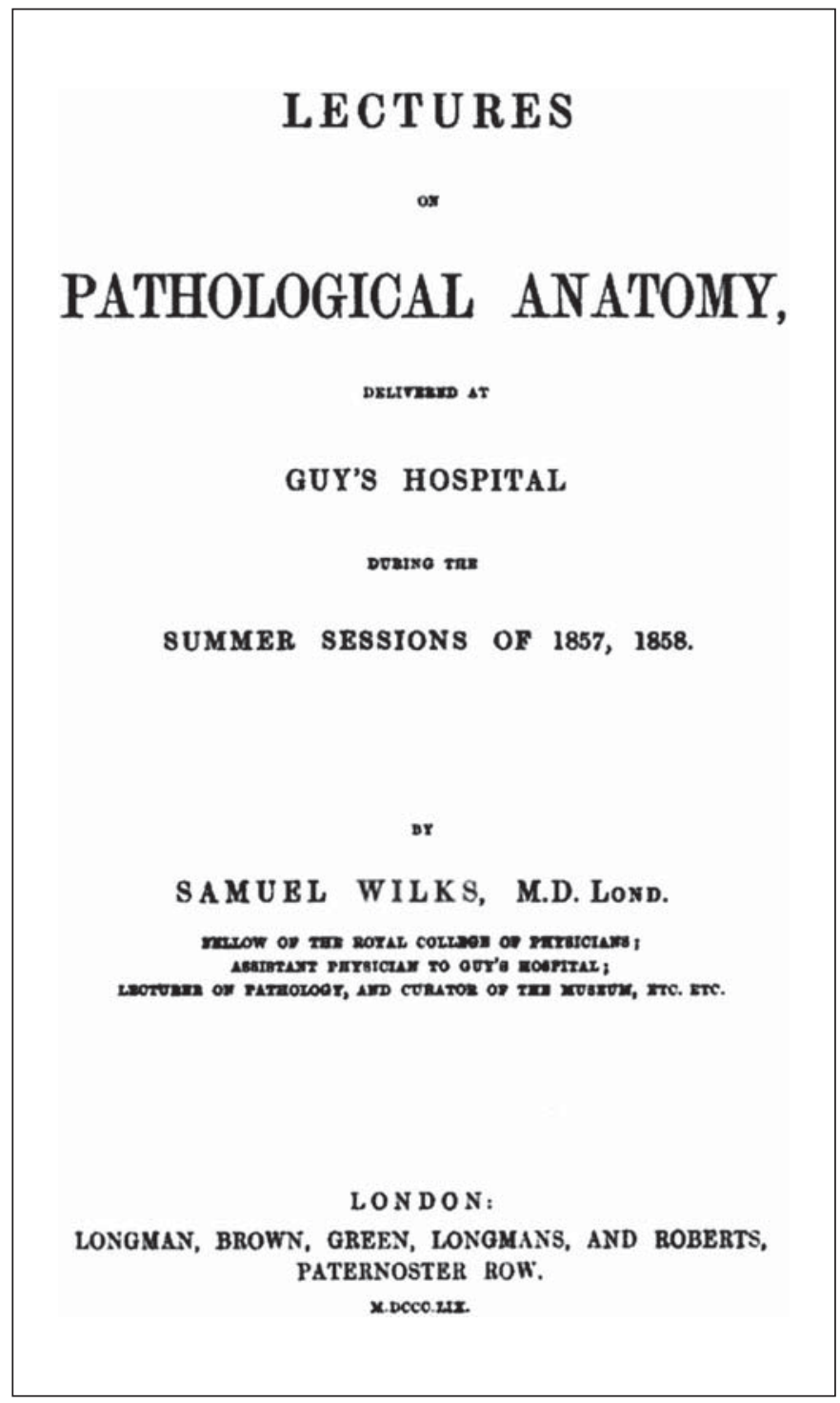

Fig. 1. Title page of Wilks's Lectures on Pathological Anatomy, 1859.

bone on the meninges were considered as among the causes of this affection; as, however, in the most marked examples of epilepsy, and where the disease has been of years' duration, no very evident alteration is discoverable, we call those only true cases of epilepsy where there is an absence of all manifest change in the brain, and if we discover a tumour or exostosis, we should designate the disease by these names, and not by epilepsy.

It is necessary thus to limit the term and confine it within certain boundaries, before attempting to study its pathology; and this is no artificial distinction, for, as Bright long ago observed, in epilepsy arising from a local disease the consciousness is generally present, which is not the case in the true form of the disease. In those who have been subject to epilepsy, no constant appearances are found, although very commonly those changes are seen 
in the cranium, brain, and its membranes, which are generally supposed to denote a chronic inflammatory process; but then the question remains whether this may not be rather an effect of the epilepsy than be a cause of it; ...

I have never seen but two deaths during the paroxysm, and there the morbid appearances were those due merely to asphyxia, great congestion of all the organs, brain with its vessels full of blood, lungs highly congested and exuding serum, and bronchial tubes full of frothy mucus; moreover, it could not be said that the brain was more congested than other viscera. Where patients have died with epileptiform symptoms arising from a local cause, this has generally been a tumor near the surface of the brain, or local disease of the bone, ... and it is in this situation, no doubt, where the deposit exists which causes the fits observed in syphilitic cases.'

Thus Wilks, like Bright, firmly viewed the cortex as the prime source of epilepsy [18]. He diagnosed true epilepsy only when there was no manifest change in the brain, i.e. idiopathic epilepsy. In keeping with contemporary ideas he used the word epileptiform symptoms when fits arose from a local cause, e.g. exostosis, tumour or syphilis. However, he appreciated the uncertainty of this categorization - that was not used by Jackson - when he commented:

'the very fact of definite lesions having been found shows that these cases were not examples of true epilepsy; and indeed, it may be said that they are sometimes different from those of that disease. There is some truth in this; but at the same time it appears to me that, if the same cause is sufficient to produce a certain set of symptoms, an analogous cause should be sought whenever similar symptoms are witnessed.'

In contrast, Brown-Séquard [5; pp. 180-183] had observed: 'the medulla is the most frequent seat of the disease ... there is no radical difference between the symptoms of sympathetic epilepsy, and those of the pretended ${ }^{2}$ idiopathic.'

Epilepsy until Wilks's time was defined by loss of consciousness, usually convulsions, and when he stated that 'consciousness was retained when epilepsy was caused by local disease', he probably recognized that focal epilepsy was not attended by convulsions. Wilks did not clearly identify varying impairments of consciousness and Jacksonian 'dreamy states'. He also observed the rarity of death during fits, and when it did occur he related it to asphyxia, and gave a convincing account of terminal pulmonary oedema.

His work and ideas were carried forward by John Thompson Dickson ${ }^{3}$ (1841-1874) [19], his erstwhile student at Guy's Hospital, who accepted and promoted the

\footnotetext{
2 Brown-Séquard, with remarkable prescience, scorned the use of idiopathic in relation to epilepsy.
}

cortical localization of discrete neurological functions [20] and the cortical basis of epilepsy [21]. In this, his opinions slightly predated but were closely allied to those of Hughlings Jackson. However, Dickson did not attribute epileptic phenomena to cortical excitation, rather he talked of inhibition of function ('the impoverishment of the brain tissue and the imperfection of the vitality of the cell') which, if sufficiently severe, would cause widespread cerebral vasospasm leading to brain anaemia, and thus culminate in unconsciousness. Harking back to an earlier idea that the striatum governed motor functions, he thought that reduction of cortical function would release motor activity in the corpora striata with consequent convulsive motor movements of the limbs. Jackson acknowledged Dickson's principle that an epileptic discharge might release the suppression of striatal function, but disagreed with this as a mechanism for convulsive activity, which Jackson held resulted from cortical excitation [22].

\section{Bromide, the First Anticonvulsant}

Wilks confirmed Locock's advocacy of bromides in epilepsy [23]. At a meeting of the Royal Medical and Chirurgical Society in London on Tuesday, 11 May 1857, Edward H. Sieveking presented 52 cases of epilepsy (published in Lancet 1857;i:528). In the subsequent discussion, the President of the Society, Sir Charles Locock, Queen Victoria's physician reported he had used potassium bromide to treat what he called hysterical epilepsy (in most instances menstrual or catamenial fits). Radcliffe, too, reported success with bromides [24], but the treatment was not widely adopted. Wilks appears to have independently discovered its utility, writing in his Lecture on Diseases of the Nervous System (1878):

'... being in the habit of using the iodide in epilepsy. I substituted the bromide for it. I was at first under the impression that it was acting as an absorbent, and was picking out for its operations those cases where the disease had a syphilitic or local origin; but when the cures came to be numerous, the explanation would not apply, and it was evident that a very valuable specific remedy had been obtained ... I was not aware at that time that Sir C Locock had recommended its use ...'

With just caution he stated:

'It is a great question whether this remedy which has so powerful an influence in checking the fits is really curative; whether

3 Dickson died suddenly, aged only 32, in his Brougham carriage of complications of rheumatic mitral valve disease. 
indeed it has a permanent effect on the brain to render it less unstable.'

He also wittily indicated the lack of efficacy of other remedies:

'If any old woman had the possession of a herb or a salt which could antagonise the disease, the knowledge would be worth more than that of the whole College of Physicians.'

Friedlander [25] has commented that the introduction of bromide for the treatment of epilepsy was an important episode in the history of neurology, and the individ- ual responsible for it is therefore deserving of special recognition. He said, 'This accolade is generally given to Sir Charles Locock. However, both C. Bland Radcliffe and Sir Samuel Wilks are at least as deserving of the honor.'

We can conclude that although Wilks's ideas of epilepsy versus epileptiform seizures have been superseded, after Bright, he did contribute to important and significant advances in the cortical genesis of epilepsy. He was largely responsible for the general use of bromide, which was in his day the only effective anticonvulsant.

\section{References}

1 Pearce JMS: Sir Samuel Wilks (1824-1911): 'The most philosophical of English physicians'. Eur Neurol 2009;61:119-123.

2 Jackson JH: Evolution and dissolution of the nervous system. Lancet 1884;i:555-558, 649-652, 739-744.

-3 Jackson JH: On temporary paralysis after epileptiform and epileptic seizures: a contribution to the study of dissolution of the nervous system. Brain 1881;3:433-451.

4 Jackson JH: A Study of Convulsions. St Andrew's Medical Graduates' Association. Transactions, 1869. London, Churchill, 1870, pp 162-204.

5 Brown-Séquard CE: Course of Lectures on the Physiology and Pathology of the Central Nervous System Delivered at the Royal College of Surgeons, England, May 1858. Philadelphia, Collins, 1860, lecture XI: On the Aetiology, Nature and Treatment of Epilepsy, pp 178-186. http://books.google.co.uk/ books?id=wnPMMurNpBAC\&pg=RA1 PA106\&vq=epilepsy\&dq=Lecture + Diseases + of + the + Nervous + System $\& 1 \mathrm{l}=\& \operatorname{sig}=\mathrm{p} 5 \mathrm{uxc}$ clwYz6j9ZvzEMtFdd94a6Y\#PPA185,M1.

6 Pearce JMS: Early accounts of epilepsy; in Pearce JMS (ed): Fragments of Neurological History. London, Imperial College Press, 2003, pp 181-191.

7 Brown-Séquard E: Researches on Epilepsy: Its Artificial Production in Animals, and Its Etiology, Nature and Treatment in Man. Boston, Clapp, 1857.

8 Jackson JH: Notes on the physiology and pathology of the nervous system. Med Times Gaz 1868;2:696.
9 Jackson JH: A study of convulsions - transactions of the St Andrew's Medical Graduates' Association (1870, vol 3, pp 162-204); reprinted in Taylor J (ed): Selected Writings of John Hughlings Jackson. London, Staples Press, 1958, vol 1, 1958, pp 8-36.

10 Jackson JH: On the anatomical and physiological localisation of movements in the brain - preface (London, J\&A Churchill, 1875); reprinted in Taylor J (ed): Selected Writings of John Hughlings Jackson. London, Staples Press, 1958, vol 1, 1958, pp 3776.

11 Pearce JMS: Théodore Herpin: neglected contributions in the understanding of epilepsy. Eur Neurol 2005;54:135-139.

12 Herpin T: Des accès incomplets d'épilepsie. Paris, Baillière, 1867 (translation available: http://visualiseur.bnf.fr/Visualiseur? Destination $=$ Gallica $\& O=N U M M-76917)$.

13 Herpin T: Du prognostic et du traitement curatif de l'épilepsie. Paris, Baillière, 1852.

14 Bright R: Reports of Medical Cases Selected with a View of Illustrating the Symptoms and Cure of Diseases by Reference to Morbid Anatomy. London, Longman, 1831, vol 2: Diseases of the Brain and Nervous System, part 2, p 538 (see also Berry D, Mackenzie C: Eponymists in Medicine: Richard Bright, 1789-1858. Physician in an Age of Revolution and Reform. London, Royal Society of Medicine, 1992).
15 Todd RB: On the pathology and treatment of convulsive diseases. London Med Gaz 1849; 8:822.

16 Wilks S: Observations on the pathology of some of the diseases of the nervous system. Guys Hosp Rep 1866;12:157-244.

17 Wilks S: Lectures on Pathological Anatomy Delivered at Guy's Hospital. London, Longman, 1859, part 2, p 438. http://books.google. com/books?id=0iF1eCRJotIC\&pg=PA438\& $\mathrm{lpg}=\mathrm{PA} 438 \& \mathrm{dq}=$ epilepsy+wilks\&source $=\mathrm{w}$ eb\&ots=HigNeqlcRd\&sig=WEhigv3fVVx4 4eJjZBxDSCmXSA4\#PPA438,M1.

18 Eadie MJ: Cortical epileptogenesis - Hughlings Jackson and his predecessors. Epilepsia 2007;48:2010-2015.

19 Eadie MJ: The epileptology of John Thompson Dickson (1841-1874). Epilepsia 2007;48: 22-30.

20 Dickson JT: Matter and force considered in relation to mental and cerebral phenomena. J Ment Sci 1869;16:217-239.

21 Dickson JT: On the nature of the condition called epilepsy. Lancet 1872;100:251-252, 290-291.

22 Jackson JH: Intellectual warnings of epileptic seizures (1876); in Taylor J (ed): Selected Writings of John Hughlings Jackson. London, Staples Press, 1958, vol 1, pp 274-275.

23 Pearce JMS: Bromide, the first effective antiepileptic agent. J Neurol Neurosurg Psychiatry 2002;72:412.

24 Radcliffe CB: Lectures on Epilepsy, Pain and Paralysis. London, 1864, p 223.

25 Friedlander WJ: Who was 'the father of bromide treatment of epilepsy'? Arch Neurol 1986;43:505-507. 